\title{
Self Regulated Learning dalam Mengikuti Mata Pelajaran Pendidikan Agama Kristen di SMP Negeri 6 Palangka Raya
}

\author{
Danella Merdiasi, Lilyantie, Nika Kristiani \\ Institut Agama Kristen Negeri Palangka Raya \\ Email: danellamerdiasi@gmail.com
}

\begin{abstract}
Self-regulated learning is a process of regulating and controlling, monitoring motivation and academic goals, managing human and material resources, as well as becoming a determining behavior in the decision-making process and implemention when the learning process is received. This study aims to determine the level of self-regulated learning in students who take the Christian Religion Education Subject at SMP Negeri 6 Palangka Raya. The research method used is quantitative-descriptive. The population in this study were 81 students with a sample of 68 respondents. The researcher conducted a right-tailed $t$-test and looked for the $t$-value of the entire obtained data. The results of the calculation of the One Sample T-Test in this study is obtained from the $t$-table < from the t-value $(1.66792<37.202)$. The highest level of self-regulated learning is $47.1 \%$, the medium level is $41.2 \%$ and the lowest level is $11.8 \%$. It can be concluded that self-regulated learning owned by students who take the Christian Religion Education Subject at SMP Negeri 6 Palangka Raya has a high level of 47.1\% during online teaching and learning activities.
\end{abstract}

Keywords: self regulated learning; christian religion education; student

\begin{abstract}
Abstrak
Self regulated learning merupakan proses mengatur dan mengontrol, memonitor motivasi dan tujuan akademik, mengelola sumber daya manusia dan benda, serta menjadi perilaku yang menentukandalam proses pengambilan keputusan dan pelaksana ketika proses belajar yang diterimanya. Penelitian ini bertujuan untuk mengetahui tingkat self regulated learning pada siswa yang mengikuti mata pelajaran pendidikan agama kristen di SMP Negeri 6 Palangka Raya. Metode penelitian yang digunakan adalah kuantitatif-deskriptif. Populasi pada penelitian ini adalah sebanyak 81 siswa dengan sampel 68 responden. Peneliti melakukan uji T pihak kanan dan mencari nilai $t_{\text {hitung }}$ dari keseluruhan data yang didapat. Hasil perhitungan uji One Sample T-Test penelitian ini diperoleh $t_{\text {tabel }} \leq$ darit $t_{\text {hitung }}(1.66792 \leq 37,202)$. Terdapat tingkat self regulated learning tertinggi sebesar 47,1\%, tingkat sedang sebesar 41,2 \% dan pada tingkat terendahnya berada pada 11,8 \%. Dapat disimpulkan bahwa Self Regulated Learning yang dimiliki oleh siswa-siswi yang mengikuti Mata Pelajaran Pendidikan Agama Kristen di SMP Negeri 6 Palangka Raya memiliki tingkat yang tinggi yakni 47,1 \% selama kegiatan belajar mengajar secara online atau daring.
\end{abstract}

Kata Kunci: self regulated learning; pendidikan agama kristen; siswa 


\section{Pendahuluan}

Pendidikan merupakan suatu usaha dalam memanusiakan manusia. Jadi, maksudnya adalah manusialah yang menjadi sasaran pendidikan untuk ditumbuhkembangkan potensi maupun bakatnya melalui pengalaman. ${ }^{1}$ Menurut Undang- Undang No. 20 Tahun 2003 Pasal 1 yakni pendidikan merupakan suatu usaha sadar terencana untuk mewujudkan suasana belajar agar peserta didik dapat secara aktif mengembangkan potensinya untuk memiliki kekuatan spiritual keagamaan, pengendalian diri, kepribadian, kecerdasan, akhlak mulia, serta keterampilan yang diperlukan bukan hanya bagi diri sendiri melainkan juga masyarakat, bangsa serta negara.

Pendidikan terdiri atas komponen-komponen yang memiliki pengaruh dalam membentuk pola interaksi. Komponen ini terdiri dari tujuan,pendidik, peserta didik, materi, metode, media, alat peraga dan lingkungan pendidikan. ${ }^{2}$ Seperti yang kita ketahui tujuan diadakannya pendidikan adalah berusaha untuk mencerdaskan generasi penerus bangsa. Menjadi negara yangmaju, diperlukan generasi-generasi yang siap dengan kemajuan teknologi, serta siap akan tantangan-tantangan baru dalam menghadapi kemajuan zaman. Secara idealnya generasi yang siap dalam menghadapi tantangan-tantangan dari kemajuan zaman tersebut merupakan peserta didik yang mampu untuk selaluberpikir kreatif, mandiri, aktif serta seorang peserta didik yang bertanggung jawabatas pendidikan yang sedang ia jalani.

Pada masa pandemi covid-19 ini, peserta didik dihadapkan dengan tantangan baru, yakni perubahan strategi dalam pembelajaran yang awalnya dilaksanakan dengan tatap muka berubah menjadi pembelajaran non-tatap muka atau yang dinamakan pembelajaran online atau daring. Peserta didik melaksanakan kegiatan belajar dari rumah namun tetap di jadwal yang sama seperti pada saat sekolah biasanya. Hal ini juga dilakukan dengan bimbingan orang tua di rumah serta pemantauan dan monitoring yang dilakukan oleh guru dari sekolah. Hanum berpendapat, pembelajaran online atau e-learning adalah salah satu bentuk model pembelajaran yang difasilitasi dan didukung pemanfaatan teknologi informasi dan komunikasi. ${ }^{3}$ Aktivitas belajar mengajar yang dilaksanakan secara online atau daring, biasanya menggunakan aplikasi seperti aplikasi google classroom dan whatsapp. Google classroom ini sendiri merupakan salah satu aplikasi yang digunakan dalam melaksanakan proses belajar mengajar selama masa pandemiini. Dari penyampaian tujuan pembelajaran, penyampaian materi maupunpengumpulan tugas harian yang dilaksanakan pada setiap kali pertemuan. Penggunaan google classroom juga ditunjang

1 Syafril \& Zen Zelhendri, Dasar-Dasar Ilmu Pendidikan (Depok: Kencana, 2017).

2 Ibid.

${ }^{3}$ Andri Anugrahana, "Hambatan, Solusi Dan Harapan: Pembelajaran Daring Selama Masa Pandemi Covid-19 Oleh Guru Sekolah Dasar," Scholaria: Jurnal Pendidikan dan Kebudayaan 10, no. 3 (2020): 282-289. 
dengan aplikasi whatsapp yangterdiri atas grup kelas guna pengisian presensi peserta didik walaupun sebenarnya dapat dilakukan langsung pada google classroom. Dalam penggunaan aplikasi- aplikasi tersebut tentunya guru dan peserta didik dituntut untuk selalu belajar dalam menggunakan teknologi dan menguasai media-media pembelajaran agar materi yang tersampaikan dapat dimengerti dan dipahami dengan baik.

Begitu juga halnya yang terjadi di SMP Negeri 6 Palangka Raya yaitu proses belajar mengajar menggunakan metode daring, salah satunya pada mata pelajaran Pendidikan Agama Kristen. Mata pelajaran Pendidikan Agama Kristen di SMP Negeri 6 Palangka Raya dilaksanakan 1 kali dalam seminggu dan dilakukan pada pukul 10.00 WIB hingga pukul 12.00 WIB. Seluruh kelas dari kelas VII hingga kelas IX dilaksanakan pada hari Senin saja. Dari masing-masing tingkatan ini, terdiri atas 3 guru agama Kristen yakni guru kelas VII, VIII dan IX. Pada kelas VII, terdapat 9 kelas yang terdiri dari 81 siswa yang mengikuti mata pelajaran Pendidikan Agama Kristen. Di dalam google classroom, 9 kelas ini terbagi menjadi 9 ruangan yang terdiri dari 8 hingga 10 siswa dalam setiap ruangannya. Pada setiap pertemuan yang dilaksanakan, secara bergiliran guru akan memberikan materi yang dapat berupa instruksi pada peserta didik untuk membuka buku paket atau menyimak video yang diberikan di bagian forum yang ada di google classroom, biasanya pada bagian akhir/penutupan pembelajaran guru juga memberikan tugas yang harus dikerjakan oleh peserta didik. Tugas ini diberikan batasan waktu pengerjaan selama 5 hari untuk dikumpulkan kembali kepada guru di bagian tugas google classroom. Peserta didik diberikan kesempatan untuk menanggapi maupun memberi pertanyaan pada saat proses pembelajaran apabila masih kurang memahami dan tidak mengerti terkait dengan materi yang disampaikan di google classroom. Jika terdapat peserta didik yang bertanya, guru tidak langsung menjawab secara cepat karena waktu pembelajaran dilaksanakan bersamaan yaknipukul 10:00 WIB dari kelas VII-1 hingga kelas VII-9 sehingga guru memerlukan waktu untuk memantau ke masing-masing kelas yang ada di google classroom.

Pada realita yang terjadi terdapat banyak hambatan dalam pelaksanaan pembelajaran ini, seperti: hambatan dialami oleh siswa yang harus lebih banyak belajar dalam menggunakan teknologi, contohnya seperti penggunaan google classroom dan aplikasi penunjang seperti power point maupun video untuk dapat mengikuti materi pembelajaran. Terkadang dalam penyampaian materi pembelajaran, guru tidak ada memberikan penjelasan terkait materi yang dibahas dan hanya dibaca oleh peserta didik. Hal ini tentu memiliki pengaruh pada pembelajaran yang dilaksanakan. Kemudian hambatan yang di alami oleh peserta didik lainnya seperti terdapat banyak peserta didik yang tidak melakukan pengumpulan tugas pada batas waktu yang telah ditentukan (5 hari setelah pemberian tugas) dalam setiap pertemuan, ada yang tidak 
mengisi presensi hingga pertemuan berikutnya, ketika mengumpulkan tugas ada yang menjawab pertanyaan seadanya, hal tersebut nampak dari hasil evaluasi yang diperoleh.

Peserta didik memiliki berbagai alasan tidak mengumpulkan tugas seperti tidak memiliki buku paket ${ }^{4}$, tidak hadir sama sekali pada setiap pertemuan pembelajaran yang dilaksanakan di google classroom dan tugas dari mata pelajaran lain juga menumpuk atau banyak ${ }^{5}$ serta terdapat siswa yang tidak mengumpulkan tugas sama sekali dengan alasan mendahulukan tugas mata pelajaran yang lain terlebih dahulu. ${ }^{6}$

Berdasarkan wawancara awal yang dilakukan dengan beberapa siswa bahwa mata pelajaran Pendidikan Agama Kristen merupakan salah satu mata pelajaran yang kurang begitu diminati oleh peserta didik di SMP Negeri 6 Palangka Raya. Hal ini dikarenakan penyampaian materi yang kurang dimengerti dan dipahami peserta didik. Padahal mata pelajaran Pendidikan Agama Kristen penting untuk dipelajari oleh peserta didik. Ryan dan Bohlin berpendapat bahwa pendidikan karakter (dalam konteks sekolah)adalah upaya menolong para peserta didik untuk mengetahui yang baik, mencintaiapa yang baik, dan melakukan yang baik. ${ }^{7}$ Melalui Pendidikan Agama Kristen yang ada di sekolah, karakter peserta didik dibentuk untuk belajar Pendidikan Agama Kristen dengan baik. Peserta didik yang telah belajar Pendidikan Agama Kristen akan menerapkan etika yang baik dalam kehidupannya sehari-hari, meskipun secara nilai akademiknya kurang tetapi dalam kehidupannya sehari-hari tetap menerapkan etika yang baik, seperti: mempunyai karakter yang jujur, sopan, menghargai orang lain dan menghormati orang yang lebih tua darinya.

Dalam hal ini tidak semua peserta didik yang menjalani pendidikan mampu untuk secara aktif dan mandiri dalam mengatur, mengontrol maupun memonitor proses belajar yang diterimanya. Pengaturan dalam proses belajar seorang peserta didik ini diperlukan guna mencapai tujuan yang inginkan. Jika peserta didik ini memiliki self-regulated learning yang baik dalam proses kognitifnya tentu peserta didik ini dapat mengatur dan mengelola agar sesuatu yang dikerjakannya dapat sukses serta memiliki nilai yang bagus. Peserta didik yang memiliki self-regulatedlearning yang baik akan memiliki pengaturan terhadap proses pembelajaran yang dilakukannya seperti menyelesaikan tugas-tugas yang diberikan oleh guru secara baik. ${ }^{8}$ Dalam Self-regulated learninng, individu sendirilah yang mengatur dan mengontrol, memonitor motivasi

\footnotetext{
4 Rain Natanabel (siswa), Hasil wawancara via Chat Whatsapp, 15 Februari 2021, Pukul. 17.09 WIB.

5 Teteng (Guru PAK SMP Negeri 6 Palangka Raya), Hasil Wawancara, 22 Februari 2021, Guru menjelaskan banyak tugas-tugas mata pelajaran lainnya yang diberikan guru buat siswa.

${ }^{6}$ Agnie Cynthia (Siswa), Hasil wawancara via Chat Whatsapp, 08 Maret 2021, Pukul. 10.21 WIB

7 Daniel Nuhamara, "Pengutamaan Dimensi Karakter Dalam Pendidikan Agama Kristen," Jurnal Jaffray 16, no. 1 (2018): 93.

8 Putri Yulianti, Sano Afrizal, and Ifdil, "Self Regulated Learning Siswa Dilihat Dari Hasil Belajar," Jurnal EDUCATIO: Jurnal Pendidikan Indonesia 2, no. April (2016): 98-102.
} 
dan tujuan akademik, mengelola sumber daya manusia dan benda, serta menjadi perilaku yang menentukan dalam proses pengambilan keputusan dan pelaksana ketika proses belajar yang diterimanya.

Menurut Pintrich \& De Groot, self-regulated learning adalah sebuah istilah dalam proses belajar dan menjelaskan tentang kegiatan belajar yang diatur oleh diri sendiri yang mencakup kegiatan individu dalam mengaktifkan pikiran, motivasi, dan tingkah laku untuk mencapai tujuan belajarnya. ${ }^{9}$ Berdasarkan pendapat tersebut dapat dipahami bahwa self-regulated learning merupakan suatu proses belajar yang melibatkan pikiran, motivasi dan tingkah laku yang bertujuan untuk mencapai goal dari proses belajar yang telah diterimanya.

Komponen-komponen yang penting dalam self regulated learning yakni metakognitif, motivasional, strategi kognitif dan kelola sumber daya. ${ }^{10}$ Metakognitif menurut pendapat Schraw \& Perling-Dennison merupakan kemampuan untuk merefleksikan, memahami dan mengontrol perilaku belajar. ${ }^{11}$ Komponen motivasi dalam Self Regulated Learning (SRL) terdiri atas efikasi diri dan minat intrinsik terhadap tugas. ${ }^{12}$ Motivasi yakni suatu dorongan yang dimiliki oleh diri sendiri dalam menyelesaikan tugasnya. Efikasi yang terdapat pada diri adalah keyakinan yang dimiliki terhadap kemampuannya. Komponen strategi kognitif merupakan tindakan nyata yang digunakan siswa untuk belajar, mengingat dan memahami materi. ${ }^{13}$ Menurut Gagne, strategi kognitif adalah kemampuan yang terdapat dalam diri seseorang dengan terorganisasi dengan baik sehingga hal tersebut membantudalam proses belajar, berpikir, pemecahan masalah dan pengambilan keputusan. ${ }^{14}$ Self regulated learning secara sederhananya dapat dipahami dengan mampu (skill) dan mau (wiil) belajar dengan pengertian seseorang. Pada komponen kelola sumber daya ini meliputi beberapa hal yakni menyeleksi, mengatur dan mengendalikan lingkungan untuk mengoptimalkan belajar. ${ }^{15}$ Strategi yang terdapat pada komponen ini juga meliputi pencarian bantuan, informasi pengarahan diri sendiri saat belajar, serta penentuan tempat yang ideal untuk belajar. Strategi ini sangat berguna untuk seorang pesera didik dalam menyesuaikan diri dengan lingkungan belajar yang sesuai dengan kebutuhannya.

\footnotetext{
${ }^{9}$ Radhyan Hardhito and Tino Leonardi, “Gambaran Self-Regulated Learning Pada Mahasiswa Yang Tidak Menyelesaikan Skripsi Dalam Waktu Satu Semester Di Fakultas Psikologi Universitas Airlangga," Jurnal Psikologi Pendidikan dan Perkembangan 5, no. 1 (2016): 1-11.

10 Titik Kristiyani, Self Regulated Learning Konsep, Implikasi, Dan Tantangannya Bagi Siswa Di Indonesia, Sanata Dharma University Press, Yogyakarta, 2016.

11 Ibid., 18.

12 Ibid., 22.

13 Ibid., 25.

14 Desmita, Psikologi Perkembangan Peserta Didik (Bandung: PT Remaja Rosdakarya, 2009).

15 Kristiyani, Self Regulated Learning Konsep, Implikasi, Dan Tantangannya Bagi Siswa Di Indonesia.
} 
Self regulated learning dipengaruhi oleh faktor internal dan faktor eksternal. Faktor internal meliputi pengetahuan, motivasi serta kemampuan yang dimiliki ${ }^{16}$. Sedangkan faktor eksternal yaitu faktor keluarga, faktor sekolah, dan faktor teman sebaya. Peserta didik perlu memiliki sebuah regulasi diri agar dapat mencapai tujuannya dengan lebih terarah. Untuk itu diperlukannya pengelolaan diri yang baik guna mengontrol diri serta bertanggung jawab atas dirinya sendiri. Peserta didik yang mempunyai regulasi diri yang baik yakni peserta didik yang mampu menyampaikan gagasan serta tindakan yang baik. Peserta didik yang memiliki kesadaran akan kegiatan maupun aktivitas yangdilakukan biasanya adalah pembelajar yang aktif. Hal ini dapat diperhatikan ketika peserta didik tersebut mengikuti pembelajaran serta pemahamannya pada setiap materi yang diberikan di kelas. Namun terkadang masih ada peserta didik yang kurang mampu dalam mengatur pelaksanaan ketika proses belajar. ${ }^{17}$

Peserta didik yang memiliki self-regulated learning yang tinggi dapat mengorganisir pekerjaan mereka, menetapkan tujuan, mencari bantuan ketika diperlukan, menggunakan strategi kerja yang efektif, mengatur waktu mereka untuk belajar dan memiliki efikasi diri18 sehingga peserta didik tersebut dapat menyelesaikan setiap pekerjaan yang berupa tugas tanpa mengalami kesulitan. Sedangkan peserta didik yang memiliki self-regulated learning yang rendah yaitu di mana siswa tersebut kurang mampu dalam menyimak, merespon, memperhatikan dan menanggapi. ${ }^{19}$ Sering kali peserta didik tidak memiliki tujuan yang jelas dalam belajarnya. Dengan memiliki kemampuan regulasi diri yang baik ini dapat membantu mereka dalam memiliki kebiasan-kebiasaan yang positif seperti belajar yang baik dan memiliki percaya diri atas kemampuan yang dimilikinya. Tentu dengan regulasi ini dapat meningkatkan usaha dari peserta didik dalam mencapai hasil belajar.

Berdasarkan hasil penelitian yang dikemukakan oleh Sutikno menjelaskan bahwa self-regulated learning mempunyai kontribusi yang signifikan dalam pembelajaran dan meningkatkan prestasi hasil belajar siswa. ${ }^{20} \mathrm{Hal}$ ini berbeda dengan hasil penelitian yang dilakukan oleh Cetin yaitu tidak adanya korelasi antara hasil

${ }^{16}$ Siti Suminarti Fasikhah and Siti Fatimah, "Self-Regulated Learning DALAM MENINGKATKAN PRESTASI AKADEMIK PADA MAHASISWA," 21st Century Education: A Reference Handbook 21st century education: A reference handbook 01, no. 01 (2013): I-175-I-183.

17 Widayat Prihartanta, "Teori-Teori Motivasi," Jurnal Adabiya, Tahun 2015 Vol. 1 No., no. 83

(2015): 1-11, https://www.academia.com.

${ }^{18}$ Mega Famela, "Pengaruh Regulasi Diri, Iklim Sekolah, Dan Dukungan Sosial Terhadap Kemandirian Belajar Siswa Smp Ypui Jakarta Selatan" (2019): 15-24.

${ }^{19}$ De La Fuente, “Differential Effects of Self- vs. External-Regulation on Learning Approaches, Academic Achievement, and Satisfaction in Undergraduate Students," https://www.ncbi.nlm.nih.gov/pmc/articles/PMC7575817/.

${ }^{20}$ Sutikno, “Kontribusi Self Regulated Learning Dalam Pembelajaran," no. 76 (2016): 188-203. 
belajar (IPK) dengan motivasi dan self-regulated learning. ${ }^{21}$ Dengan kata lain, motivasi akademik dan SRL tidak dapat memprediksi hasil belajar (IPK). Penelitian ini penting untuk dilakukan supaya setelah mengetahui kemampuan self-regulated learning atau pengelolaan terhadap proses belajar pada peserta didik di SMP Negeri 6 Palangka Raya sehingga dapat menjadi bahan evaluasi bagi peserta didik, sekolah maupun orang tua agar dapat berusaha secara maksimal dalam mengelola proses belajar dan mencapai tujuan yang diinginkan. Adapun tujuan dari penelitian ini yaitu mengetahui tingkat Self-Regulated Learning (SRL) dalam mengikuti mata pelajaran Pendidikan Agama Kristen pada siswa di SMP Negeri 6 Palangka Raya. Hipotesis dari penelitian ini adalah H0 :Siswa memiliki tingkat Self Regulated Learning $\leq 55,6 \%$, berarti lebih rendah dan H1: Siswa memiliki tingkat Self Regulated Learning > 55,6 \%, berarti lebih tinggi. Rumusan masalah pada penelitian ini yaitu seberapa besar tingkat SelfRegulated Learning (SRL) dalam mengikuti matapelajaran Pendidikan Agama Kristen pada siswa di SMP Negeri 6 Palangka Raya?.

\section{Metode}

Penelitian ini menggunakan metode penelitian kuantitatif dengan jenis penelitian yaitu penelitian deskriptif. Penelitian yang hanya melibatkan satu variabel yaitu Self Regulated Learning pada satu kelompok, tanpa menghubungkan dengan variabel lain atau membandingkan dengan kelompok lain. Penelitian ini dilaksanakan di SMP Negeri 6 Palangka Raya, Jalan Seth Adji, Panarung, kecamatan Pahandut, Kota Palangka Raya, Provinsi Kalimantan Tengah dengan Populasi subyek penelitian berjumlah 81 orang dan sampel penelitian yang digunakan berjumlah 68 siswa yaitu terdiri dari siswa kelas VII yang aktif mengikuti mata pelajaran Pendidikan Agama Kristen. Penelitian ini dilaksanakan dalam waktu 2 bulan terhitung mulai tanggal 26 April hingga 26 Juni 2021 yang meliputi tahap observasi awal, merancang instrumen, uji validitas dan reliabilitas instrumen, pengambilan data, analisis data dan pembuatan laporan penelitian. Pengumpulan data pada penelitian ini yaitu dengan menggunakan angket Self Regulated Learning (SRL). Angket ini disusun menggunakan rentang skala Likert dengan makna.

Self regulated learning diukur menggunakan skala Motivated Strategies for learning Questionnaire (MSLQ) yang dikembangkan oleh Pintrich ${ }^{22}$. Aspek-aspek yang terdapat pada self-regulated learning berupa: 1) metakognitif, 2) motivasional yang terdiri atas intrinsic goal orientation, extrinsic goal motivation, task value, control of learning beliefs, self efficacy for learning, dan test anxiety, 3) strategi belajar yang terdiri atas rehearsal, elaboration, organization, critical thinking, metacognitive self regulation, time and

${ }^{21}$ Cetin Baris, "Academic Motivation And Self Regulated Learning in Predicting Academic Achievement In College," Journal of International Education Research 11, no. 2 (2015): 95-106.

${ }^{22}$ Asina Christina Rosito, "Kepribadian Dan Self-Regulated Learning," Jurnal Psikologi 45, no. 3 (2018): 189. 
study environment, effort regulation, help seeking dan peer learning, 4) kelola sumber daya yang meliputi pencarian bantuan, informasi pengarahan diri sendiri saat belajar serta penentuan tempat yang ideal untuk belajar. Angket akan disebar melalui google form yang telah tersedia pertanyaan- pertanyaan yang berkaitan dengan Self Regulated Learning (SRL). Melalui angket yang diberikan kepada responden inilah, akan dikumpulkan data berupa jawaban yang telah di isi oleh responden. Butir angket disusun berdasarkan indikator self regulated learning yaitu aspek metakognitif dengan jumlah item sebanyak 10 yang meliputi indikator merencanakan, mengorganisasikan, dan mengukur diri. Aspek kedua yaitu motivasional dengan jumlah item sebanyak 10 yang meliputi Intrinsic goal orientation, Extrinsic goal orientation, Task value, Control of learning belief, Selfefficacy for learning. Aspek ketiga yaitu strategi belajar dengan jumlah item sebanyak 9 yang meliputi indikator Rehearsal, Metacognitive selfregulation, Time and studyenvironment, Effort regulation, Help seeking, Peer learning. Aspek keempat yaitu kelola sumber daya dengan jumlah item sebanyak 3 yang meliputi indikator pencarian bantuan dan penentuan tempat belajar.

Uji coba instrumen dilakukan oleh peneliti di luar populasi penelitian. Untuk melaksanakan uji coba instrumen, peneliti mengambil 20 responden siswa kelas VII di SMP Kristen Palangka Raya. Berdasarkan uji validitas terhadap instrumen angket self regulated learning yaitu dari 32 butir angket terdapat 8 butir angket yang tidak valid, yakni nomor 2, 9, 12, 16, 22, 25, 27, dan 31 sehingga terdapat 24 butir angket yang valid. Berdasarkan uji reliabilitas, dapat disimpulkan bahwa angket Self Regulated Learning (SRL) dinyatakan reliabel karena nilai dari Cornbach's Alpha $\geq 0,70$. Analisis data menggunakan analisis statistik deskriptif dengan menggunakan bantuan software statistik SPSS 21. Analisis statistik deskriptif adalah analisis yang terkait dengan pengumpulan data, penyajian, penentuan nilai-nilai statistika, pembuatan diagram atau gambar, data yang dikumpulkan dan disajikan dalam bentuk yang mudah dipahami serta dibaca. ${ }^{23}$ Analisis statistik dekriptif dalam penelitian ini akan menggambarkan nilai rata-rata (mean), nilai maksimum, nilai minimum serta kategori dari self-regulated learning pada siswa yang mengikuti mata pelajaran Pendidikan Agama Kristen. Setelah mendapatkan hasil nilai rata-rata (mean), nilai maksimum, nilai minimum dan standar deviasi, maka selanjutnya data akan dikategorikan berdasarkan tingkatnya yakni rendah, sedang dan tinggi.

\section{Hasil dan Pembahasan}

\section{Hasil Penelitian}

Peneliti mendeskripsikan data penelitian untuk menggambarkan tingkat self regulated learning selama mengikuti mata pelajaran Pendidikan Agama Kristen. Data

${ }^{23}$ Leni Masnidar Nasution, “STATISTIK DESKRIPTIF," Jurnal Hikmah 14 (2017): 49-55, https://docplayer.info/47282311-Statistik-deskriptif-leni-masnidar-nasution.html. 
mengenai self regulated learning diperoleh melalui penyebaran angket yang terdiri dari 24 butir pernyataan kepada 68 subjek Kelas VII Mata Pelajaran Pendidikan Agama Kristen di SMP Negeri 6 Palangka Raya. Data yang telah diperoleh tersebut, selanjutnya ditabulasikan dan dihitung nilai rata- rata (mean), modus (mo), median (me), serta standar deviasinya menggunakan bantuan dari software SPSS 21. Berdasarkan data perhitungan tersebut diperoleh hasil dari nilai skala yang sudah disebarkan dari 68 siswa yaitu mean 99,15 dengan nilai maximum 116 dan nilai minimum 72 dengan standar deviasi 9,653.

Setelah nilai mean dan standar deviasi diperoleh, langkah selajutnya data self regulated learning akan dikategorikan berdasarkan tingkatnya yakni rendah, sedang dan tinggi. Adapun penentuan kategorinya sebagai berikut:

Tabel 5. 3 Penentuan Kategori SRL

\begin{tabular}{|c|c|c|c|}
\hline No & Rentang Skor & Kategori & Skor Skala \\
\hline 1 & $\mathrm{X}<\mathrm{M}-1 \mathrm{SD}$ & Rendah & $\mathrm{X}<72$ \\
\hline 2 & $\mathrm{M}-1 \mathrm{SD} \leq \mathrm{X}<\mathrm{M}+1$ & Sedang & $89<=\mathrm{X}<99$ \\
& $\mathrm{SD}$ & & \\
\hline 3 & $\mathrm{M}+1 \mathrm{SD} \leq \mathrm{X}$ & Tinggi & $\leq \mathrm{X} 116$ \\
\hline
\end{tabular}

Berdasarkan hasil distribusi frekuensi dari keseluruhan total 68 subjek. Peneliti menarik kesimpulan bahwa terdapat self regulated learning dalam mengikuti Mata Pelajaran Pendidikan Agama Kristen pada siswa kelas VII di SMP Negeri 6 Palangka Raya berada pada kategori tinggi.

Pada proses pengujian hasil penelitian, peneliti melakukan ujinormalitas dan homogenitas yang menunjukkan bahwa data dalam penelitian ini berdistribusi normal dan homogen. Berdasarkan hasil uji normalitas, nilai dari one sample kolmogorov-smirnov Z adalah 0,828 dengan Asymp. Sig. (2-tailed) 0,500 yang dimana nilai signifikasi $\mathrm{p}>0.05$, dapat kita simpulkan bahwa data berdistribusi normal. Berdasarkan nilai Self Regulated Learning pada siswa yang mengikuti Mata pelajaran Pendidikan Agama Kristen di Kelas VII SMP Negeri 6 Palangka Raya, hasil uji homogenitas varians data yang didapatkan adalah 0,022 (sig > 0,05). Maka dengan demikian dapat disimpulkan bahwa data varian tersebut adalah sama (homogen).

Setelah peneliti melakukan pengujian normalitas dan homogenitas, peneliti juga melakukan pengujian hipotesis menggunakan uji one sample T-Test, dengan uji pihak kanan. Berdasarkan dari perhitungan uji one sample T-Test atau uji t pada tabel

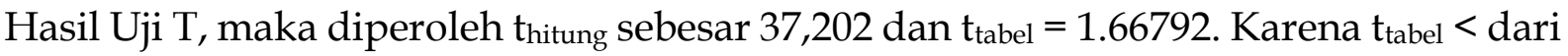
$t_{\text {hitung }}(1.66792<37,202)$, maka Ho ditolak dan H1 diterima. Artinya hipotesis alternatif (H1) yaitu tingkat self regulated learning siswa lebih besar dari 55,6\% diterima sehingga dapat diketahui bahwa terdapat tingkat self regulated learning pada siswa-siswi yang 
mengikuti mata pelajaran Pendidikan Agama Kristen kelas VII tersebut. Berdasarkan hasil penelitian diketahui bahwa tingkat kategori self regulated learning pada siswa SMP Negeri 6 Palangka Raya yaitu 11,8 \% berada pada kategori rendah, 41,2 \% berada pada kategori sedang dan 47,1 \% pada kategori tinggi. Dari persentase tersebut, secara umum dapat disimpulkan bahwa siswa yang mengikuti mata pelajaran Pendidikan Agama Kristen kelas VII di SMP Negeri 6 Palangka Raya tahun ajaran 2020/2021 ini memiliki SRL yang tinggi.

\section{Pembahasan}

Berdasarkan hasil penelitian diketahui bahwa dalam tingkat ketegori Self Regulated Learning berada di 47,1 \% atau dapat dikategorikan tinggi. Dari persentase tersebut dapat disimpulkan bahwa siswa yang mengikuti mata pelajaran Pendidikan Agama Kristen kelas VII di SMP Negeri 6 Palangka Raya ini memiliki SRL yang Tinggi dan sudah mampu untuk mengatur diri dalam mencapai tujuan dalam belajarnya. Dalam kegiatan belajar yang dilaksanakan secara online ini siswa tentu sudah dapat memanfaatkan waktu serta sumber daya yang tersedia seperti buku paket yang dipinjamkan oleh pihak sekolah dalam menunjang pembelajaran secara online, kemudian berupa barang elektronik sepertihandphone tempat untuk mengetahui informasi-informasi terkait pembelajaran.

Berdasarkan ciri-ciri yang ada dalam Self Regulated Learning digambarkan bahwa keadaan siswa selama proses pembelajaran mampu dalam menyimak, merespon, memperhatikan, menanggapi serta memiliki rasa antusias. Berdasarkan angket yang telah diisi oleh responden menggambarkan bahwa siswa memiliki tingkat SRL yang tinggi dan ciri-ciri yang ada dalam Self Regulated Learning (SRL) digambarkan melalui keadaan siswa selama proses pembelajaran yaitu dimana siswa yang memiliki Self Regulated Learning yang tinggi tersebut mampu dalam menyimak, merespon, memperhatikan, menanggapiserta memiliki rasa antusias ${ }^{24}$. Berdasarkan aspek-aspek SRL, aspek yang terendah yaitu pada aspek strategibelajar yakni 80,8 \% sehingga hal tersebut berkaitan dengan alasan-alasan yangmembuat siswa cenderung tidak melakukan pengulangan pelajaran di rumah, kurang disiplin (time management) dalam mengerjakan tugas sehingga tugas terselesaikan dalam waktu yang panjang, kurangnya kemampuan individu dalam merencanakan, mengorganisasikan, mengintruksi diri, memonitor danmelakukan evaluasi dalam aktivitas belajar. Hal ini menunjukkan bahwa siswa juga memerlukan bimbingan belajar yang baik dari guru maupun orang tua selama mata pelajaran Pendidikan Agama Kristen berlangsung secara online maupun tatap muka secara langsung.

Dengan diketahuinya kategori tingkat SRL ini, digambarkan bahwa siswa-

24 De La Fuente, "Differential Effects of Self- vs. External-Regulation on Learning Approaches, Academic Achievement, and Satisfaction in Undergraduate Students." 
siswi yang mengikuti mata pelajaran Pendidikan Agama Kristen kelas VII di SMP Negeri 6 Palangka Raya secara metakognitif, motivasional, strategibelajar dan kelola sumber dayanya sudah cukup tinggi serta didukung oleh guru yang selalu melakukan pemantauan dan bimbingan pada siswa, serta orang tua juga mengingatkan siswa tentang belajar dan tugas yang telah diberikan.

Hal ini didukung juga oleh penelitian Fitria Dwi Astatika bahwa dukungan dari lingkup keluarga turut mempengaruhi tinggi rendahnya selfregulated learning dari siswa ${ }^{25}$. Penelitian ini menemukan bahwa salah satu cara untuk meningkatkan SRL siswa salah satunya adalah dengan berlatihuntuk disiplin. Pintrich \& De Groot berpendapat bahwa self regulated learning merupakan sebuah istilah dalam proses belajar dan menjelaskan tentang kegiatan belajar yang diatur oleh diri sendiri, yang mencakup kegiatan individudalam mengaktifkan pikiran, motivasi, dan tingkah laku untuk mencapai tujuanbelajarnya ${ }^{26}$. Siswa yang telah mampu secara mandiri untuk mengatur kegiatan belajarnya selama di rumah dapat dikategorikan dalam memiliki tingkatan SRL yang tinggi sehingga hal tersebut tentu lebih mudah untukdiarahkan dalam pembelajaran serta rajin dalam menyelesaikan tugas-tugas yang diberikan oleh guru.

\section{Implikasi}

Berdasarkan pemaparan mengenai Self Regulated Learning pada siswa SMP Negeri 6 Palangka Raya di atas, maka dapat dikemukakan implikasi secara teroritis maupun implikasi secara praktis. Implikasi teoritis pada penelitian ini yaitu Self Regulated Learning memiliki peran yang penting jika diterapkan dalam proses pembelajaran yang meliputi komponen pertama yaitu metakognitif seperti merencanakan, mengorganisasian, dan mengukur diri. Komponen kedua yaitu motivasional seperti motivasi internal, motivasi eksternal dan evaluasi tugas. Komponen ketiga yaitu strategi belajar seperti pengulangan/latihan, meregulasi waktu belajar, mengatur usaha dan perhatian dari gangguan dan berdiskusi dengan teman terkait materi pembelajaran. Seorang peserta didik harus mampu menjadi regulator atau pengatur bagi belajarnya sendiri terutama pada situasi saat ini, dimana proses belajar mengajar dilakukan secara daring. ${ }^{27}$ Berdasarkan hasil penelitian, segian peserta didik di SMA Negeri 6 Palangka Raya memiliki tingkat SRL yang tinggi yaitu mereka cukup mampu dalam meregulasi kognisi, metakognisi, dan motivasi. Namun

${ }^{25}$ Fitria Dwi Astatika, “Self-Regulated Learning Pada Siswa Sekolah Menengah Pertama (SMP) 06 Muhammadiyah Dau," Skripsi: Fakultas Psikologi Universitas Muhammadiyah Malang (2018): 147, http:/ / eprints.umm.ac.id/43370/1/Script.pdf.

${ }^{26}$ Hardhito and Leonardi, “Gambaran Self-Regulated Learning Pada Mahasiswa Yang Tidak Menyelesaikan Skripsi Dalam Waktu Satu Semester Di Fakultas Psikologi Universitas Airlangga."

${ }^{27}$ Rahmad Agung Nugraha, Model-Model Self Regulated Learning Dalam Meningkatkan Prestasi Akademik Siswa (Tegal: Badan PEnerbit Universitas Pancasakti Tegal, 2019). 
hal yang masih perlu untuk ditingkatkan yaitu pada strategi belajar peserta didik seperti melakukan pengulangan/latihan lagi di rumah secara mandiri, kemampuan dalam membuat kesimpulan, analogi dan catatan, membuat kerangka hubungan dari informasi-informasi yang dipelajari serta berpikir kritis.

Implikasi secara praktis yang terdapat pada penelitian ini yaitu guru dapat meningkatkan selfregulated learning pada siswa yang memiliki tingkat self regulated learning rendah dengan menggunakan strategi-strategi dari self regulated learning, seperti: self-evaluating (evaluasi diri), organizing and transforming (mengatur dan mengubah), goal-setting and planning (menetapkan tujuan dan perencanaan), seeking information (mencari informasi), keeping records and monitoring (menyimpan catatan dan memantau), environmental structuring (mengatur lingkungan belajar), self-consequating (konsekuensi diri), rehearsing and memorizing (pelatihan dan penghafalan), seeking social assistance (pencarian bantuan), dan reviewing record (pemeriksaan laporan). Bagi orangtua peserta didik yaitu dapat membantu anak-anak belajar dengan menetapkan tujuan untuk suatuaktivitas belajar, menjaga perhatian anak-anak tetap fokus pada tugas belajar, menyarankan strategi belajar yang efektif, memonitor kemajuan belajar dan sebagainya. ${ }^{112}$ Dengan adanya bantuan dan bimbingan dari orangtua tesebut secara terus menerus, seiring waktu peserta didik akan mampu untuk mengatur dan mengelola proses belajarnya sendiri. Ketika peserta didik ini mendapat suatu dorongan dari orang terdekat kemudian juga dari guru yang selalu memonitor pekerjaan serta kemajuan dari peserta didik maka self-regulated learningnyaperlahan terbentuk dengan baik. Bagi peserta didik juga dapat mengatur dirinya sendiri terutama disiplin dalam belajar. Self regulated learning yang dimiliki oleh siswa dapat dibentukapabila siswa mampu untuk mengatur dan mengelola proses belajarnya.

\section{Rekomendasi untuk Penelitian Lanjutan}

Pada penelitian selanjutnya disarankan untuk dapat menggunakan pendekatan kualitatif agar mendapatkan data yang lebih mendalam dan secara deskriptif mengenai gambaran Self Regulated Learning yang meliputi metakognitif, motivasi dan strategi belajar yang dimiliki oleh siswa serta menggunakan alat pengumpul data (instrumen) yang lebih beragam seperti observasi dan wawancara. Hal ini dikarenakan pendekatan yang digunakan dalam penelitian ini yaitu pendekatan kuantitatif, di mana data yang tersaji berupa angka saja dalam melihat gambaran mengenai Self Regulated Learning pada siswa.

Pada penelitian ini juga, populasi hanya pada siswa SMP 6 saja sehingga pada penelitian selanjutnya direkomendasikan untuk dapat memperluas populasi penelitian seperti pada tingkat pendidikan Sekolah Dasar (SD), Sekolah Menengah Atas (SMA) dan Perguruan Tinggi serta tidak hanya pada siswa yang mengikuti mata pelajaran Pendidikan Agama Kristen tapi dapat dilakukan pada mata pelajaran yang 
lainnya. Berdasarkan hasil penelitian, Self Regulated Learning yang dimiliki oleh siswasiswi yang mengikuti Mata Pelajaran Pendidikan Agama Kristen di SMP Negeri 6 Palangka Raya mayoritas memiliki tingkat yang tinggi sehingga untuk penelitian selanjutnya juga perlu untuk diteliti mengenai faktor-faktor yang mempengaruhi Self Regulated Learning yang dimiliki oleh siswa sehingga terdapat tingkat Self Regulated Learning yang berbeda-beda seperti ada yang tinggi, sedang dan rendah.

\section{Kesimpulan}

Berdasarkan hasil perhitungan uji one sample T-Test atau uji t pihak kanan pada

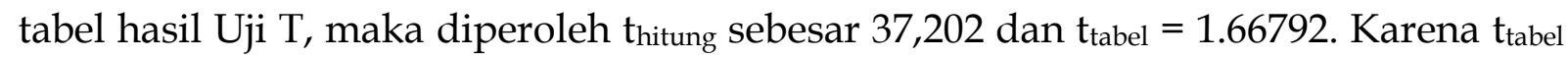
$<$ dari thitung $(1.66792<37,202)$. Artinya hipotesis alternatif $(\mathrm{H} 1)$ yaitu tingkat self regulated learning siswa lebih besar dari 55,6\% diterima. Maka, terdapat tingkatan self regulated learning pada hasil penelitian yang telah dilakukan ini. Hasil dari penelitian ini ialah dari keseluruhan total 68 subjek, yang dimanaterdapat gambaran kategori tingkat self regulated learning tertinggi sebesar $47,1 \%$, tingkat sedang sebesar $41,2 \%$ dan pada tingkat terendahnya berada pada $11,8 \%$. Hal ini menunjukkan bahwa self regulated learning yang dimiliki oleh siswa- siswi yang mengikuti Mata Pelajaran Pendidikan Agama Kristen di SMP Negeri 6Palangka Raya mayoritas memiliki tingkat yang tinggi yakni 47,1\% selama dilaksanakannya kegiatan belajar mengajar secara online atau daring.

\section{Rujukan}

Anugrahana, Andri. “Hambatan, Solusi Dan Harapan: Pembelajaran Daring Selama Masa Pandemi Covid-19 Oleh Guru Sekolah Dasar." Scholaria: Jurnal Pendidikan dan Kebudayaan 10, no. 3 (2020): 282-289.

Astatika, Fitria Dwi. “Self-Regulated Learning Pada Siswa Sekolah Menengah Pertama (SMP) 06 Muhammadiyah Dau." Skripsi: Fakultas Psikologi Universitas Muhammadiyah Malang (2018): 1-47. http:/ / eprints.umm.ac.id/43370/1/Script.pdf.

Cetin Baris. "Academic Motivation And Self Regulated Learning in Predicting Academic Achievement In College." Journal of International Education Research 11, no. 2 (2015): 95-106.

Desmita. Psikologi Perkembangan Peserta Didik. Bandung: PT Remaja Rosdakarya, 2009.

Famela, Mega. “Pengaruh Regulasi Diri, Iklim Sekolah, Dan Dukungan Sosial Terhadap Kemandirian Belajar Siswa Smp Ypui Jakarta Selatan" (2019): 15-24.

Fasikhah, Siti Suminarti, and Siti Fatimah. "Self-Regulated Learning DALAM MENINGKATKAN PRESTASI AKADEMIK PADA MAHASISWA." 21st Century Education: A Reference Handbook 21st century education: A reference handbook 01, no. 01 (2013): I-175-I-183.

Hardhito, Radhyan, and Tino Leonardi. "Gambaran Self-Regulated Learning Pada Mahasiswa Yang Tidak Menyelesaikan Skripsi Dalam Waktu Satu Semester Di 
Fakultas Psikologi Universitas Airlangga." Jurnal Psikologi Pendidikan dan Perkembangan 5, no. 1 (2016): 1-11.

Kristiyani, Titik. Self Regulated Learning Konsep, Implikasi, Dan Tantangannya Bagi Siswa Di Indonesia. Sanata Dharma University Press, Yogyakarta, 2016.

De La Fuente. “Differential Effects of Self- vs. External-Regulation on Learning Approaches, Academic Achievement, and Satisfaction in Undergraduate Students." https://www.ncbi.nlm.nih.gov/pmc/articles/PMC7575817/.

Nasution, Leni Masnidar. "STATISTIK DESKRIPTIF." Jurnal Hikmah 14 (2017): 49-55. https:/ / docplayer.info/47282311-Statistik-deskriptif-leni-masnidarnasution.html.

Nugraha, Rahmad Agung. Model-Model Self Regulated Learning Dalam Meningkatkan Prestasi Akademik Siswa. Tegal: Badan PEnerbit Universitas Pancasakti Tegal, 2019.

Nuhamara, Daniel. "Pengutamaan Dimensi Karakter Dalam Pendidikan Agama Kristen." Jurnal Jaffray 16, no. 1 (2018): 93.

Prihartanta, Widayat. "Teori-Teori Motivasi." Jurnal Adabiya, Tahun 2015 Vol. 1 No., no. 83 (2015): 1-11. https:/ / www.academia.com.

Rosito, Asina Christina. "Kepribadian Dan Self-Regulated Learning." Jurnal Psikologi 45, no. 3 (2018): 189.

Sutikno. “Kontribusi Self Regulated Learning Dalam Pembelajaran," no. 76 (2016): 188-203.

Syafril \& Zen Zelhendri. Dasar-Dasar Ilmu Pendidikan. Depok: Kencana, 2017.

Yulianti, Putri, Sano Afrizal, and Ifdil. "Self Regulated Learning Siswa Dilihat Dari Hasil Belajar." Jurnal EDUCATIO: Jurnal Pendidikan Indonesia 2, no. April (2016): 98-102. 